\title{
DETERMINANT OF FINANCIAL DISTRESS: THE CASE OF PULP \& PAPER COMPANIES REGISTERED IN INDONESIA STOCK EXCHANGE
}

\author{
Augustina Kurniasih")1, Heliantono*), Agus Herta Sumarto*), Rianti Setyawasih ${ }^{* *}$, and \\ Isti Pujihastuti ${ }^{* *}$ \\ *) Mercu Buana University \\ Jl. Meruya Selatan No. 1, Kembangan, Jakarta 11650 \\ ${ }^{* * *)}$ Islamic University 45 Bekasi \\ J1. Cut Meutia No. 83, Bekasi Timur, Jawa Barat 17113
}

\begin{abstract}
The pulp and paper industry contributes to the Indonesian economy, especially to the non-oil and gas processing industry. Empirical research shows that pulp and paper companies listed on the Indonesia Stock Exchange (IDX) indicated financial distress. This study aims to find the effect of liquidity, leverage, profitability, and efficiency on pulp \& paper companies' financial distress listed on the IDX. Using the Altman Z-score as a measure of financial distress, it was found that profitability, efficiency, and liquidity had a significant adverse effect on financial distress. In contrast, leverage had a significant positive effect on financial distress. Profitability has the greatest influence on financial distress, so it needs the primary intention of management.
\end{abstract}

Keywords: financial distress, liquidity, profitability, leverage, efficiency

Abstrak: Industri pulp dan kertas berkontribusi cukup signifikan bagi perekonomian Indonesia, khususnya terhadap industry pengolahan non-migas. Penelitian empiris menunjukkan bahwa perusahaan pulp dan kertas yang terdaftar di Bursa Efek Indonesia (BEI) terindikasi mengalami financial distress. Penelitian ini bertujuan menemukan pengaruh likuiditas, leverage, profitabilitas, dan efisiensi terhadap financial distress perusahaan pulp \& kertas terdaftar di BEI. Menggunakan Altman Z-score sebagai ukuran financial distress ditemukan bahwa profitabilitas, efisiensi, dan likuiditas, berpengaruh negatif signifikan terhadap financial distress, sedangkan leverage berpengaruh positif signifikan terhadap financial distress. Profitabilitas memberi pengaruh terbesar terhadap financial distress, sehingga perlu mendapat perhatian utama dari manajemen perusahaan.

Kata kunci: financial distress, likuiditas, profitabilitas, leverage, efisiensi

\footnotetext{
${ }^{1}$ Corresponding author:

Email: augustina.kurniasih@mercubuana.ac.id
} 


\section{INTRODUCTION}

The pulp and paper industry contributes to the Indonesian economy, with $17.6 \%$ and $6,3 \%$ shares to the non-oil and gas processing industry sector and the national processing industry sector, respectively. In 2018, the pulp and paper industry's GDP grew 1.1\% (yoy) and BPS (government bureau of statistics) records in 2019 the paper industry, including paper goods and printing industry, contributed $3.95 \%$ to the non-oil and gas processing industry with a growth of $8.14 \%$ (Marjudin, 2020).

The pulp and paper industry is expected to grow by $5 \%$ in 2019. The Indonesian Pulp and Paper Association (APKI) assesses that global and domestic demand is still increasing at 2\% (yoy). In 2019 Indonesia's pulp \& paper industry was among the top 10 largest producers in the world. In the Asia region, Indonesia is the thirdlargest producer for the pulp industry and fourth for the paper industry (Rini, 2019).

However, the research of Kurniasih et al. (2019) shows that pulp and paper companies listed on the IDX are in an unhealthy condition or experiencing financial distress. Based on the Z-Score calculation, it was found that during 2013-2017 more than half $(52,5 \%)$ of the pulp and paper companies listed on the Indonesia Stock Exchange were at high risk of bankruptcy, while the rest were potentially bankrupt (47.5\%).

Table-1. Z-score and Category of Corporate Financial Difficulties

\begin{tabular}{ccc}
\hline \multirow{2}{*}{ Year } & \multicolumn{2}{c}{ Number of Company $(\%)$} \\
\cline { 2 - 3 } & $1,23<$ Z-score $<2,99$ & Z-score $<1,23$ \\
\cline { 2 - 3 } & (potentially bankrupt) & (high risk to bankrupt) \\
\hline 2013 & 62.5 & 37.5 \\
2014 & 50 & 50 \\
2015 & 25 & 75 \\
2016 & 50 & 50 \\
2017 & 50 & 50 \\
\hline
\end{tabular}

Source: Kurniasih et al. (2019)

Pulp and paper industry products are needed by the community, especially in education and offices. Therefore this industry still exists. The data in Table-1 shows that the pulp and paper companies listed on the Indonesia Stock Exchange in the 2013-2017 period have a low Altman Z-score, which indicates that they are in a bad financial situation. Companies that experience financial problems and are not handled properly can result in bankruptcy.

Financial distress could be influenced by liquidity, leverage, profitability, and firm's efficiency. Liquidity shows the company's ability to pay off short-term financial obligations was found to positively and significantly affect financial distress (Pranowo et al. 2010; Ufo, 2015; Kristanti et al. 2016, Nurhayati et al. 2017). Masdupi et al. 2018) found the influence of negative and significant liquidity on financial distress. As for Roslan (2014), Mburu (2018), Jaafar et al. (2018), and Fatimah et al. (2019) found liquidity did not affect financial distress.

Leverage is a ratio that shows a company's ability to pay off long-term obligations. This variable was found to have a negative and significant effect on financial distress (Pranowo et al. 2010; Ufo, 2015; Kristanti et al. 2016; Jaafar et al. 2018; Masdupi et al. 2018), while Roslan (2014), Nurhayati et al. (2017), and Fatimah et al. (2019) found leverage to have a positive and significant effect on financial distress. Akpinar and Akpinar (2017) and Mburu (2018) find leverage does not affect financial distress.

Profitability is the company's ability to make a profit. Roslan (2014), Ufo (2015), Akpinar and Akpinar (2017), Jaafar (2018), and Mburu (2018) found profitability to have a positive and significant effect on financial distress. While Pranowo et al. (2010), Nurhayati et al. (2017), and Masdupi et al. (2018) found a negative and significant effect.

A company's efficiency in conducting its business was found to have a positive and significant effect on financial distress (Pranowo, 2010 and Ufo, 2015). However, Nurhayati et al. (2017) and Mburu (2018) found that efficiency did not affect the company's financial distress.

Pulp \& paper industry has an important role in the Indonesian economy, showing by its absorption of 1,49 million employees in 2016 (Afriyadi, 2017) and 1.36 million in 2018, consisting of 260,000 direct workers and 1.1 million indirect workers (Setyawati, 2019).

The Stock Exchange shows that more than $50 \%$ of them experience financial distress and are likely to go bankrupt. The research problems to be answered in 
this study are: Do liquidity, leverage, profitability, and efficiency affect the financial distress of pulp and paper companies? The research questions will be resolved using a multiple linear regression approach.

Financial difficulties occur when a company fails or is unable to fulfill its obligations to creditors and cannot manage and maintain financial performance stability. Plat and Plat (2006) explain that the beginning of failure is when a company fails to promote its products, causing sales to decline. A decline in sales can result in a decline in company profits - the smaller the profit, the lower the possibility that the company can retain profits to increase equity. Retained earnings are a source of internal funding. Therefore when internal sources are insufficient, the company will seek external funding, one of which is debt. The bigger the debt, the higher the company's liability, which, if not appropriately managed, can result in financial problems (financial distress). Financial distress, which is not managed carefully and followed by appropriate action, can cause companies to go bankrupt.

Bankruptcy analysis is carried out to obtain an early warning of bankruptcy (early signs of bankruptcy). The earlier signs of bankruptcy known and aware, the better for the management, since management can make improvements and correction to avoid it. On the other hand, creditors and shareholders can make preparations to overcome various bad possibilities. Signs of bankruptcy, in this case, can be seen from the occurrence of financial distress.

Short-term financial difficulties are temporary and are usually not severe. However, if it is not handled correctly, such difficulties can develop into nonsolvable difficulties. If it comes to a condition of not solvable, the company can be liquidated (Hanafi and Halim, 2003).

Bankruptcy is usually interpreted as a condition or situation where the company fails or is no longer able to meet the debtor's obligations since the company experiences shortages and insufficient funds to run or continue its business. Financial distress is a situation where the company's operating cash flow cannot cover or meet the company's obligations at the time, such as Letters of Credit (L/C) or interest charge, so the company is forced to take corrective action. Financial distress can bring a company to default on its contract, which in the end, must be financially restructured by creditors and capital investors (equity investors) of the company.

Unfortunately, financial difficulties are challenging to detect. Financial difficulties can mean from liquidity difficulties (short term) to bankruptcy statements. Liquidity difficulties are the mildest difficulties, while the statement of bankruptcy is the most severe difficulty. Empirical research usually uses a bankruptcy statement as a definition of bankruptcy.

Previous researchers have done several studies related to financial distress and factors that influence its financial distress. There are several approaches used by researchers to measure financial distress, namely debt service coverage (Pranowo et al. 2010; Pranowo et al. 2011; Ufo, 2015), interest coverage ratio (Utami et al. 2019), companies experience losses (Nurhayati et al. 2017; Masdupi et al. 2018), and many researchers use the Altman Z-score (Endri, 2009; Kurniasih et al. 2014; Akpinar \& Akpinar, 2017; Jafaar et al. 2018; Mburu 2018; Kurniasih et al. 2019). Previous research has been carried out in various countries, such as Indonesia, Malaysia, Turkey, Ethiopia, Nairobi, and various industries such as non-financial companies (i.e., property, necessary, and chemical industries), state-owned enterprises, and family companies. It was concluded that several factors that influence financial distress were profitability, leverage, liquidity, and efficiency, concluding that the study results were still different. This study aims to find empirical evidence of the effect of liquidity, leverage, profitability, and efficiency on pulp \& paper companies' financial distress in 2013-2018.

Jensen \& Meckling (1976) initiated agency theory, a theory that shows a problem between principal and agent. These problems can be between the owner (shareholder) with the manager (management) or between the owner (shareholder) with the debt holder (bondholder). When a company uses a lot of debt to fund its operational and investment activities, agency problems are more likely to occur between the company owner and the debt holder or between management and debt holders. Increasing the use of debt increases the likelihood of financial distress.

Donaldson and Davis (1991) explained that if agency theory argues that shareholders' interests need protection by separating the positions of chairman of 
directors from CEOs, the Stewardship Theory believes that the same shareholders maximize shareholder interests. Stewardship theory describes a situation where management is not motivated by individual goals but rather the organization's interests. Thus, when a company uses funding from debt to finance its investment, it is executed solely for the company's purposes; for instance, it is an effort to get the cheapest funding for the company (minimum cost of capital).

The trade-off theory (Modigliani-Miller, 1963) states that companies have an optimal debt-equity ratio. When it has not reached the optimal point, the company should increase debt since there are tax benefits from debt (tax shield). When it reaches its optimal point, the company should no longer add debt because an increase in debt will increase the potential for bankruptcy, eliminating the tax benefits of debt.

Ross et al. (2016) explained that companies with a greater risk of experiencing financial distress would borrow less than companies with lower financial distress risk. The costs of financial distress differ from one company to another. The cost of financial distress mainly depends on the company's assets, which will determine how easily the assets' ownership can be transferred. This study aims to find the effect of liquidity, leverage, profitability, and efficiency on pulp \& paper companies' financial distress listed on the IDX.

\section{METHODS}

The research was conducted in Indonesia covering 6 years period of 2013-2018. The research was conducted in Indonesia Stock Exchange on the Pulp \& Paper sector listed on the Indonesia Stock Exchange, 20132018. The data used are secondary data, which are cross-section and time-series.

Data is collected by using the literary method by recording the figures presented in the company's financial statements. Data obtained from the company's Financial Statement (Audited) through the website www.idx.co.id. Data needed include value of current assets, current debt, total assets, sales revenue, net income, dividend payments, retained earnings, EBIT, total debt, and total equity.
This research is a causality research that aims to find empirical evidence of the influence of independent variables on the dependent variable. The independent variables of this study are liquidity, leverage, profitability, and company efficiency. The dependent variable is financial distress. Data analysis techniques is using panel data regression approach. The research framework is presented in Figure 1.

Altman (1968) uses the Multiple Discriminant Analysis method, which produced a score known as the Altman $\mathrm{Z}$-score. The score shows the condition of the company in connection with the possibility of bankruptcy. Altman uses five types of financial ratios, which are (1) working capital to total assets, (2) retained earnings to total assets, (3) earnings before interest and taxes to total assets, (4) market value of equity to book value of total debts, and (5) sales to total assets.

Until present the Z-Score is still widely use by researchers, practitioners, and academicians in the accounting than other prediction models. The results of the research developed by Altman, are shown in an equation, i.e:

$$
Z=1.2 Z_{1}+1.4 Z_{2}+3.3 Z_{3}+0.6 Z_{4}+0.999 Z_{5}
$$

Notes: $Z_{1}$ (working capital/total asset); $Z_{2}$ (retained earnings/total asset); $Z_{3}$ (earnings before interest and taxes/total asset); $Z_{4}$ (market capitalization/book value of debt); $Z_{5}$ (sales/total asset).

The model developed by Altman underwent a revision. The revision made by Altman is an adjustment so that the bankruptcy prediction model is not only use for the going public manufacturing companies but can also be applied to companies in the private sector.

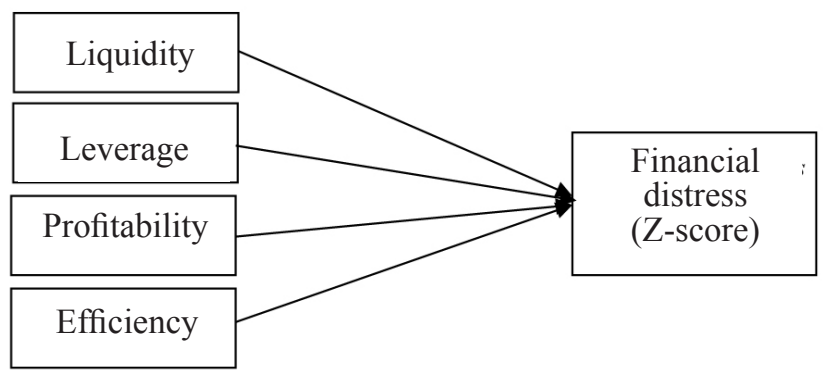

Figure 1. The research framework 
The old model experienced a change in one of the variables used, which is revised to be:

$$
Z^{\prime}=0.71 Z_{1}+0.847 Z_{2}+3.10 Z_{3}+0.420 Z_{4}+0.998 Z_{5}
$$

Notes: $Z_{1}$ (working capital/total asset); $Z_{2}$ (retained earnings/total assets); $Z_{3}$ (earnings before interest and taxes/total asset); $Z_{4}$ (book value of equity/book value of debt); $Z_{5}$ (sales/total asset).

Based on the latest formula, Altman divides companies based on Z-scores:

a. If the Z-score $<1.23$, the company is categorized as an unhealthy company and has a large financial problem and the risk of the company experiencing bankruptcy is very large.

b. If $1.23<Z$-score $<2.99$, the company has the potential to go bankrupt

c. If Z-Socre $>2.99$, the company is included in the healthy criteria.

The accuracy of the Altman Z-score model reaches 90 percent of the actual events. Based on the research results, it can be concluded that the closer to the time of bankruptcy, the greater the level of validity of the results of predictions made with the model.

Z-Score values, in general, can be used by investors to assess their investments' security since they can be used to protect investors when investing in companies that can go bankrupt. However, this approach's users should be careful in interpreting the value, especially concerning its relevance to the industrial conditions in which the company is located.

The dependent variable of this study is financial distress as measured by the Altman score (Z-score), ie:

$$
Z^{\prime}=0.71 Z_{1}+0.847 Z_{2}+3.10 Z_{3}+0.420 Z_{4}+0.998 Z_{5}
$$

The independent variables of this study and their measurements are presented in the following sections:

(a) Liquidity. Measured from the company's ability to pay off its short-term liabilities using current assets. The size used is the current ratio (CR).

$$
\mathrm{CR}=\text { Current Asset / Current Liability }
$$

(b) Leverage. Measured from the proportion of longterm debt to total equity.

\section{LEV $=$ Total long term liability / Total equity}

(c) Profitability. Measuring the company's ability to generate net income from the use of assets held. A measure of return on assets (ROA) is used.

$$
\mathrm{ROA}=\text { Net profit } / \text { Total asset }
$$

(d) Company Efficiency. Measured from the efficiency of a company using assets to generate sales, or can be called a total asset turn over (TATO).

$$
\text { TATO }=\text { Sales } / \text { Total Asset }
$$

The research data collected was tabulated using the Excel program. The research data is panel data therefore it is processed using the EViews Program. To answers the research questions this research uses a panel data multiple linear regression approach. Regression equation compiled is as below.

$\mathrm{FD}_{\mathrm{it}}=\mathrm{a}_{0}+\mathrm{b}_{1} \mathrm{LIK}_{\mathrm{it}}+\mathrm{b}_{2} \mathrm{LEV}_{\mathrm{it}}+\mathrm{b}_{3} \mathrm{PROF}_{\mathrm{it}}+\mathrm{b}_{4} \mathrm{EFIS}_{\mathrm{it}}+\varepsilon_{\mathrm{it}}$

where: FD (financial distress); LIK (liquidity); LEV (leverage); PROF (profitability); EFIS (company efficiency); $a_{0}$ (intercept); $b_{1}, b_{2}, b_{3}, b_{4}$ (regression coefficient); $\varepsilon$ (error term)

Since the research data is panel data, the first analysis is performed to determine the best panel model. The best panel model will be determined through the Chow Test, Hausman Test, and LM Test.

Chow Test Hypothesis:

H0: The best model is PLS

H1: The best model is not PLS

If the Chow test results are accepting H0, then the best model is PLS. If the Chow test results reject $\mathrm{HO}$, then the Hausman test is necessary.

The Hausman Test Hypothesis

H0: the best model is REM

H1: The best model is FEM

To increase confidence in selecting the best model, an LM test can be performed. The LM test hypothesis is $\mathrm{H} 0$ : the best model is PLS

$\mathrm{H} 1$ : the best model is REM 
A good multiple regression model is the best linear unbiased estimator. For these reasons, it is necessary to test the classical assumptions. The classical assumption test in panel data will depend on the estimation method/ model used. If the estimation model used is Pooled Least Square (PLS) or Fixed Effect Models (FEM), then the classic assumption test used is the error/residual normality test, heteroscedastic, autocorrelation test, and multicollinearity test. However, suppose the estimation model used is the Random Effects Model (REM). In that case, heteroscedasticity and autocorrelation tests are not needed since the REM method uses the General Least Square (GLS) approach.

After the classical assumptions are fulfilled, an analysis of the suitability of the regression model is developed. The goodness of fit model is decided based on the results of the F test. The model's ability to explain the variability of the problem in terms of the coefficient of determination. After it is found that the model is fit, a partial analysis is performed to determine each independent variable's effect on the dependent variable. The effect of the independent variables is analyzed from the regression coefficient values of each independent variable. If the regression coefficient of the independent variable $\neq 0$ means that the variable affects the dependent variable. Furthermore, the significance of each variable's effect is tested through the t-test or t-student (Suharyadi and Purwanto, 2016) if the value of the t-count is more significant than the $\mathrm{t}$-table or the significance value $<\alpha=5 \%$, the variable has a significant effect.

\section{RESULT}

The data processing results on the dependent variable, and the independent variable produce a description of the data, as presented in Table 2. The average value of Altman Z-Score from eight Pulp and Paper companies is 1.3136 . The average value shows that, in general, the Pulp \& Paper company is in the potentially bankrupt classification $(1.23<$ Z-score $<2.99)$. The maximum value of the $Z$-score of 2.9565 indicates that the company is not in a healthy condition. The minimum Z-score of -0.7593 shows that the company has an immense potential to go bankrupt. The maximum and minimum Z-score values recorded by PT Pabrik Kertas
Basuki Rachmat Indonesia, Tbk (KBRI), throughout 2013 - 2018. In 2018, the value of sales dropped dramatically from IDR144,027,720,203 in 2017 to IDR2,871,460,630 in 2018.

The average company liquidity is 1.4045 , which shows the company as an average liquid. The liquidity is measured by the current ratio (CR) so that it can be explained that on an average of every 100 units of current debt, there are 140.45 units of current assets to serve it off. The maximum value of CR 3.7614 is recorded by PT Suparma, Tbk (SPMA), in 2014. The KBRI owned the minimum CR value of 0.0526 in 2018. The minimum CR value shows that the KBRI is in an illiquid condition, which means that the company cannot pay off its short-term obligations. This illiquid condition has been experienced by the PT Pabrik Kertas Basuki Rachmat Indonesia, Tbk (KBRI), since 2015.

DER measures the leverage variable. DER's average value is 1.6177 , which shows that the company is unsolvable on average since there is a total debt of Rp 161.77 for every IDR100 of equity. A company with a DER of more than 1 means that the company is more heavily financed by debt, not by equity. Thus, if the company is liquidated, the company will not pay its short-term and long-term obligations.

The highest DER was 5,2404, experienced by the KBRI in 2018. While the lowest DER was 0.1378 also experienced by the KBRI (in 2013), it means in 2013 the KBRI was very low using debt as a source of funding, but in 2018 the use of debt as a source of the fund by KBRI moved to very high.

ROA measures the profitability variable. The average value of ROA of 0.0205 shows that the average Pulp \& Paper Company is profitable. Each IDR100 asset can generate a net profit of IDR2.05. The maximum ROA value of 0.1282 is experienced by PT Fajar Surya Wisesa, Tbk (FASW), in 2018. The KBRI experiences the minimum ROA value of -0.1178 in 2018 , which shows that KBRI had a negative EBIT. The Z-score formula shows that EBIT has the most significant role in determining the Z-score than other accounts, namely working capital, retained earnings, the book value of equity, and sales. 
TATO measures the efficiency variable. The average value of 0.7469 shows that each IDR100 of the company's assets, on average, can generate sales of IDR74.69. TATO's maximum value reached 1.7468, experienced by PT Kedawung Setia Industrial, Tbk (KDSI), in 2016. The KBRI experienced the minimum value of TATO 0.0027 in 2018 .

Efforts to find empirical evidence of factors that influence the potential bankruptcy of the Pulp \& Paper company are carried out using a multiple linear regression approach. The data used in this study is panel data, which combines cross-section data with time-series data. Testing the best panel model using the Chow test shows the value of Prob. F is 0.1658 , so there is not enough evidence to reject H0. This means the best model is Pooled Least Square (PLS).

The PLS model's use has implications for the need to do a classic assumption test on the regression equation used. For this reason, a residual normality test, a heteroscedasticity test, an autocorrelation test, and a coefficient (multicollinearity) test are performed. The classical regression assumption's test results show no autocorrelation and multicollinearity, but the error distribution is not normal, and there are heteroscedasticity symptoms. To overcome the problem of not fulfilling the classical regression assumption test, an outlier test is used. It is known that three data become outlier data. Therefore the three data were excluded from observation.

Without including outlier data, the results of data processing regarding the effect of liquidity, leverage, profitability, and efficiency using the PLS model are presented in Table 3. It can be seen that the F-statistic value is 688.45, with a Prob F value of 0.0000. It can be concluded that together similarly, the four independent variables significantly influence the dependent variable at the 99 percent confidence level. It can be concluded that the regression model developed is fit.

The coefficient of determination (Adj R-Square) 0.9843. This means that together liquidity, leverage, profitability, and efficiency can explain the Z-score variability of $98.43 \%$. There are still $1.57 \%$ of other factors that influence the Z-score, which are not included in this research model.

Table 2. Description of research variables

\begin{tabular}{lcccc}
\hline Variable & Mean & Std. Dev. & Min & Max \\
\hline Altmanm Z-Score (Z) & 1.3136 & 0.8296 & -0.7593 & 2.9565 \\
Liquidity (X1) & 1.4045 & 0.6827 & 0.0526 & 3.7614 \\
Leverage (X2) & 1.6178 & 0.7273 & 0.1378 & 5.2404 \\
Profitability (X3) & 0.0205 & 0.0529 & -0.1178 & 0.1282 \\
Efficiency (X4) & 0.7469 & 0.5382 & 0.0027 & 1.7468 \\
\hline
\end{tabular}

Table 3. Effect of liquidity, leverage, profitability, and company efficiency on the Z-score of pulp \& paper companies on the 2013-2018 BEI with pooled least square model (meet Classical assumptions)

\begin{tabular}{lccc}
\hline Variable & Reg.Coef. & $\mathrm{t}_{\text {staisicic }}$ & Prob \\
\hline Constanta & 0.4494 & 5.23 & 0.0000 \\
Liquidity (CR) & 0.0945 & 4.02 & 0.000 \\
Leverage (DER) & -0.1528 & -3.98 & 0.000 \\
Profitability (ROA & 3.4258 & 8.63 & 0.000 \\
Efficiency (TATO) & 1.1582 & 35.57 & 0.000 \\
\hline R2 & 0.9857 & & \\
Adj-R & 0.9843 & & 0.0000 \\
F-statistic & & 688.45 & \\
\hline
\end{tabular}


Table 3 shows that all independent variables significantly affect financial distress since all Prob values are below 0.05 . The resulting regression equation is as follows:

$$
\begin{aligned}
\mathrm{FD}_{\mathrm{i}}= & 0.4494+0.0945 \mathrm{LIK}_{\mathrm{i}}-0.1528 \mathrm{LEV}_{\mathrm{i}}+3.4258 \mathrm{PROF}_{\mathrm{i}} \\
& +1.1582 \mathrm{EFIS}_{\mathrm{it}}
\end{aligned}
$$

Constanta is 0.4494 with a significance of 0,000 , shows that if the liquidity ratio, leverage, profitability, and efficiency is zero, the company's Z-score is 0.4494 . It means the company is categorized as an unhealthy company and faces financial distress, and the risk of the company experiencing a bankruptcy is very high.

The liquidity regression coefficient is 0.0945 . It means liquidity has a positive and significant effect on $\mathrm{Z}$-scores. If liquidity increases by 1 unit, the Z-score will increase by 0.0945 , ceteris paribus.

The leverage regression coefficient is $-1,528$. It means leverage has a negative and significant effect on $Z$-scores. The coefficient value indicates that if leverage increases by 1 unit, the Z-score will decrease by 1.528 , ceteris paribus.

The profitability regression coefficient is 3,4258 . It means profitability has a positive and significant effect on Z-scores. The profitability coefficient's value shows that if the company's net profit over the use of assets increases by 1 unit, the Z-score will increase by 3.5258 , ceteris paribus.

The efficiency regression coefficient is 1.1582. It means efficiency has a positive and significant effect on Z-scores. The efficiency coefficient value indicates that if a company's efficiency in using assets to produce sales increases by 1 unit, the Z-score will increase by 1.1582 , ceteris paribus.

The four independent variables in this study significantly influence the Z-score of the Pulp \& Paper company. The most significant influence comes from profitability. Thus, for the company to be in a healthy condition to avoid the potential for bankruptcy, management needs to pay attention to the ability to generate profits from assets.

\section{Managerial Implications}

This study shows that company management needs to pay more attention to generating profits than liquidity, leverage, and efficiency. The greater the profit can be achieved, the less likely financial distress will occur as Pranowo et al. (2011) found that an increase in profit will pull off the companies from experiencing financial distress and become companies that do not experience financial distress.

\section{CONCLUSIONS AND RECOMMENDATIONS}

\section{Conclusions}

This study's findings show that liquidity has a positive effect on the value of the Z-score supports the hypothesis proposed. The effect of positive and significant liquidity on the Z-score shows, the more liquid the company is, the more the $\mathrm{Z}$-score increases. Increased $\mathrm{Z}$-scores indicate that companies are less likely to experience financial difficulties. The findings of this study are in line with the results of research by Pranowo et al. (2010), Johannes (2014), Ufo (2015), and Curry and Banjarnahor (2018). Pranowo et al. (2010) examined the financial distress of non-financial companies on the Indonesia Stock Exchange in the period 2004-2008. The Pulp \& Paper Company is also a non-financial sector company included in the Basic Industry and Chemical (manufacturing) sector. Johannes (2014) and Ufo (2015) examined the financial distress of manufacturing companies in Ethiopia. Meanwhile, Curry and Banjarnahor (2018) examined property \& real estate companies listed on the IDX.

The findings of this study that leverage negatively affect the value of the Z-score supports the theory of financial distress that companies with large debts not to be able to pay off their obligations, indicating that the company is experiencing financial distress and will be able to go bankrupt. Companies that have the potential to go bankrupt have a low Z-score. The results of this study are in line with research by Pranowo et al. (2010), Ufo (2015), Jafaar et al. (2018), Masdupi et al. (2018), and Saputri and Asrori (2019). Jafaar et al. 2018 examined companies in Malaysia included in Practice Note 17, which are in financial distress and are listed on the stock exchange. Masdupi et al. (2018) examined manufacturing companies listed on the IDX. Saputri and Asrori (2019) examined mining compamodiglinies 
companies listed on the IDX in 2013-2016. So the relationship of leverage with financial distress occurs in various types of industries.

This study's findings showed that profitability has a positive effect on the Z-score's value, showing that the company can generate profits (profit). The more profitable the company, the healthier the condition, the further away from financial difficulties. This study found that profitability is the most influencing variable to companies' Z-score in the pulp \& paper industry. The results of this study are in line with the results of the research of Hafizah bint Roslan (2015), Akpinar and Akpinar (2017), Mburu (2018), and Saputri and Asrori (2019). Hafizah bint Roslan (2015) examined in Malaysia for manufacturing companies, Akpinar and Akpinar (2017) researched in Istanbul, and Mburu (2018), who study non-financial companies listed on the Nairobi Stock Exchange. Net income divided by total assets measures profitability in this study. Rafatnia et al. (2020) measure profitability with EBIT dividends by total assets. They examined listed companies on the Iranian stock exchange and found that profitability had a negative and significant effect on financial distress.

This study's findings showed that efficiency has a positive effect on the value of Z-score, and it shows that companies who are more efficient in utilizing their assets will be healthier, far from facing financial difficulties. The results of this efficiency-related study are in line with Kartika and Hasanudin (2019). They found that TATO's company activity had a significant negative effect on financial distress for infrastructure, utilities, and transportation companies listed on the Indonesia Stock Exchange 2011-2015. This study's finding is similar to Utami and Kartika (2019), who found that operating capacity, as measured by total asset turnover, has a negative and significant effect on the financial distress of property and real estate companies on the IDX.

It was found that liquidity, profitability, and efficiency had a significant negative effect on pulp and paper companies' financial distress. In contrast, leverage has a positive and significant effect. Based on the coefficient of the influence, profitability, efficiency, leverage, and liquidity influence financial distress. This study's findings that profitability is the variable with the most significant influence, in line with the findings of Christella and Osesoga (2020), examined the property and real estate sector companies listed on the IDX.

\section{Recommendations}

This finding supports the theory of financial distress; that liquid companies do not have problems paying off short-term obligations, thus showing the company is not experiencing financial difficulties. Therefore, company management needs to manage its liquidity properly. Since leverage negatively affect the value of the Z-score, management also need to manage its debt at an optimal level. The pulp \& paper industry is a mature industry, which means operationally; this industry is already efficient. Therefore, to increase profit, pulp \& paper companies need to increase their local and export revenues. In today's digital era, people tend to reduce paper consumption, but the need for tissue and other pulp products such as wrapping paper for food and drinks (tea and coffee) and packing paper such as cardboard is still open. An increase in sales revenues can also be done by entering the premium segment, namely producing high-quality pulp \& paper products, which will lead to a higher contribution margin. To increase efficiency in mature companies is to replace old machines with high-tech machines or new production method. Therefore, the company owner needs to inject funds so that the loan's interest expense does not burden the efficiency yield. Future studies can use a similar model in this study to be applied in other industries and replace the Altman Z-score to measure financial distress:

\section{REFERENCES}

Afriyadi AD. 2017. Peran industri pulp dan kertas dalam perekonomian RI. Liputan6.com https:// www.liputan6.com/bisnis/read/3194955/peranindustri-pulp-dan-kertas-dalam-perekonomianri [31 Jan 2020].

Akpinar O, Akpinar G. 2017. The determinants of financial distress: an application on Borsa Istanbul. Journal of Business Researh Turk 9(4): 932-951. https://doi.org/10.20491/ isarder.2017.366.

Altman EI. 1968. Financial ratios, discriminant analysis and the prediction of corporate bankruptcy. Journal of Finance 23(4): 189-209. https://doi. org/10.1111/j.1540-6261.1968.tb00843.x.

Christella C, Osesoga MS. 2020. The effect of leverage, profitability, instituional ownership, liquidity, firm size toward financial distress. Ultima Accounting: Jurnal Ilmu Akuntansi 11(1):13-31. 
Curry K, Erliana B. 2018. Financial Distress pada Perusahaan Sektor Properti Go Public di Indonesia. Prosiding Seminar Nasional Pakar 2018 Buku II, pp 207-221

Donaldson L, Davis JH. 1991. Stewarding theory or agency theory: CEO governance and shareholder return. Australian Journal of Management 16 (1): 49-65. https://doi. org/10.1177/031289629101600103.

Endri E. 2009. Prediksi Kebangkrutanbank untuk menghadapidanmengelolaperubahanlingkungan bisnis: analisis model Altman Z-score. Perbanas Quarterly Review 2(1): 34-50.

Fatimah F, Toha A, Prakoso A. 2019. The influence of liquidity, leverage, profitability ratio on financial distress(on real estate and property companies listed in Indonesia Stock Exchange in 20152017). Owner: Riset dan Jurnal Akuntansi 3 (1) 103-115. https://doi.org/10.33395/owner. v3i1.102.

Hafizah bint Roslan N. 2015. Determinants of financial distress among manufacturing companies in Malaysia [Thesis]. Kedah Darul Aman: Master of Science in Finance School of Business, Universiti Utara Malysia.

Hanafi MM, Halim A. 2003. Analisis Laporan Keuangan. UPP AMP YKPN. Yogyakarta.

Jafaar MN et al. 2018. Determinants of financial distress among the companies practice note 17 listed in Bursa Malaysia. Internatioanl Journal of Academic Research \& Social Sciences 8(11): 800-811. https://doi.org/10.6007/IJARBSS/v8i11/4956.

Jensen ME, Meckling WH. 1976. Theory of the firm: mangerial behavior, agency cost, and owneship structures. Journal of Financial Economics 3 (4): 305-360. https://doi.org/10.1016/0304$405 X(76) 90026-X$.

Johannes T. 2014. The Determinants of Financial Distress in the Case of Manufacturing Share Companies in Addis Ababa-Ethiopia. Thesis Degree of Master of Science. Addis AbabaEthiopia: The Department of Accounting and Finance Addis Ababa University.

Kartika R, Hasanudin. 2019. Analisis pengaruh likuiditas, leverage, dan profitabilitas terhadap financial distress pada perusahaan terbuka sektor infrastruktur, utilitas, dan transportasi. Oikonomia 15(1): 1-16.

Kristanti FT, Rahayu S, Huda AN. 2016. The determinants of financial distress on Indonesia
Family Firm. Procedia-Social and Behavioral Science 219: 440-447. https://doi.org/10.1016/j. sbspro.2016.05.018.

Kurniasih A, Heliantono S. 2014. Kapian Potensi Kebangkrutan BUMN Terdaftar di Bursa Efek Indonesia.ProsidingKonferensiIlmiahAkuntansi I: Sinergitas Peran Akuntan dan Otoritas Jasa Keuangan dalam Meningkatkan Transparansi \& Akuntabilitas Pelaporan Keuangan. Februari 2014 di Jakarta

Kurniasih A, Heliantono, Sumarto AH. 2019. Potential bankruptcy in pulp and paper companies listed on stock exchange and its impact on stock prices: the case of Indonesia. International Journal of Business Marketing and Management 4(9): 1-14.

Marjudin. 2020. Kembangkan Produk Bubur Kertas dan Pulp, Kemenperin Gandeng Perusahaan Jepang. https://www.indopremier.com/newsDetail. php?jdl=Kembangkan_Produk_Bubur_ Kertas_dan_Pulp__Kemenperin_Gandeng_ Perusahaan_Jepang\&news_id $=115605 \&$ group news $=$ IPOTNEWS \& taging_subtype $=P$ ULPDANKERTAS \&name $=\& \mathrm{search}=$ y_general\&q=produk $\% 20$ pulp $\% 20$ dan $\% 20$ kertas\&halaman=1 [23 Sept 2020].

Masdupi E, Tasman A, Davista A. 2018. The influence of liquidity, leverage, and profitability on financial distress listed manufacturing companies in Indonesia. Advance in Economics, Business and Management Research 57: 223-228. https://doi. org/10.2991/piceeba-18.2018.51.

Mburu EW. 2018. Determinants of financial distress of non-financial firms listed at the nairobi stock exchange [Thesis] Nairobi: Master of Science in Finance, School of Business University of Nairobi.

Modigliani F, Miller MH. 1963. Corporate income taxes and the cost of capital: a correction. The American Economic Review 53 (3): 433-443.

Nurhayati, Mufidah A, Kholidah AN. 2017. The determinants of financial distress of basic industry \& chemical companies listed in indonesia stock exchange. Review of Management \& Entrepreneurship 1(2): 19-26.

Platt HD, Platt MB. 2000. Understanding differences between financial distress and bankruptcy. Review of Applied Economics 2(2): 141-157.

Pranowo K, Noer AA, Manurung AH, Nunung N. 2010. Determinant of corporate financial distress in an emerging market economy: empirical evidence 
from the Indonesian Stock Exchange 2004-2008. International Research Journal of Finance and Economics Issue 52: 81-90.

Pranowo K, Noer AA, Manurung AH, Nunung N. 2011. Emergence corporate financial distress in emerging maket: empirical evidence from Indonesia Stock Exchange (IDX) 2004-2008. Jurnal Manajemen Agribisnis 8 (2): 109-113.

Rafatnia AA et al. 2020. Financial distress across firms. Journal of Environmental Treatment Technique 8 (2): 646-651.

Rini AS. 2019. Industri Pulp dan Kertas Indonesia Masuk dalam 10 Besar Dunia. https://ekonomi. bisnis.com/read/20190127/257/882862/industripulp-dan-kertas-indonesia-masuk-10-besardunia [25 Jan 2020].

Ross SA et al 2016. Fundamentals of Corporate Finance. Asia Global Edition. USA: McGraw Hill Eduaction.

Saputri L, Asrori. 2019. The effect of leverage, liquidity, profitability on financial distress with the effectiveness of the audit committee as a moderating variable. Accounting Analysis Journal 8 (1): 38-44.

Setyawati A. 2019. Industri pulp dan kertas Indonesia. https://analisis.kontan.co.id/news/industri-pulpdan-kertas-indonesia [24 Sept 2020].

Suharyadi, Purwanto SK. 2016. Statistika untuk Ekonomi dan Keuangan Modern Edisi 3. Jakarta: Salemba Empat.

Tim CK, Yap VC, Chai SN. 2011. Factors affecting financial distress: the case of malaysian public listed firms. Corporate Ownership \& Control 8(4): 345-351. https://doi.org/10.22495/ cocv8i4c3art3.

Ufo A. 2015. Determinants of financial distress in manufacturing firm of Ethiopia. Research Journal of Finance and Accounting 6(17): 9-16.

Utami IW, Titis PDK. 2019. Determinants of financial distress in property and real estate companies. The Indonesian Accounting Review 9(1): 109120. https://doi.org/10.14414/tiar.v9i1.1705. 